\title{
Physical, Chemical and Macrobenthic Invertebrate Fauna Characteristics of Swampy Water Bodies within University of Lagos, Nigeria
}

\author{
C. A. Edokpayi and A. O. Ayorinde \\ Department of Marine Sciences, Faculty of Science, University of Lagos, Nigeria
}

\begin{abstract}
A comparative study conducted on three swampy water bodies draining through the University of Lagos into the Lagos Lagoon describes the physical, chemical and macrobenthic invertebrate characteristics of these water bodies at the study sites. Three stations, one at each water body were sampled fortnightly from June to December, 2000. Water temperature, total alkalinity and salinity were the only physical and chemical conditions significantly different at the study stations. The physical and chemical conditions at stations A and B were similar and significantly different from station $\mathrm{C}$ exposed to domestic effluent, thereby, reflecting the perturbational stress at that site. A total of 43 benthic invertebrate taxa belonging to five classes, 31 families and 2424 individuals were recorded at the study stations. The study stations can be ranked as B > A > $\mathrm{C}$ and $\mathrm{B}>\mathrm{C}>\mathrm{A}$ in terms of number of taxa and number of individuals, respectively. The low number of taxa and individuals in stations A and $\mathrm{C}$ is suggestive of habitat instability. The pattern of invertebrate distribution and abundance was influenced by the fluctuations in the abundance of Oligochaeta, Hemiptera and Diptera. The taxon richness (D), genera diversity (H) and evenness (E) estimated for the study sites supported the trends observed in the numbers of taxa occurring and their abundance. The low concentrated dominance (C) calculated for station B compared to stations $\mathrm{A}$ and $\mathrm{C}$ reflects an ecologically heterogenous and relatively stable site. Morisita-Horn index showed that station $\mathrm{C}$ was dissimilar to stations A and B. Jaccard's coefficient indicated that all stations were dissimilar. In general, the faunal comparison showed that the level of exposure to urban discharges, inert pollutants and the presence of aquatic macrophytes influenced the differences in the abundance, occurrence and number of taxa at the three stations.
\end{abstract}

\section{Introduction}

Available studies on the water bodies in Lagos State, southern Nigeria are concen-trated on the Lagos Lagoon. Several ecological studies have been carried out on the plankton (Olaniyan, 1968; Nwankwo, 1988), macrobenthic invertebrate (Ajao, Fagade \& Oyenekan, 1991; Brown \& Oyenekan, 1998), pollution load (Akpata \& Ekundayo, 1978) and fish and fishery (Fagade \& Olaniyan, 1974; Solarin, 1998) of the Lagos Lagoon. The ecological status of the Lagos Lagoon have been associated with the quality of the water bodies which drains into it in addition to the domestic and industrial effluents released directly into the lagoon. However, studies on the physical, chemical and biological characteristics of rivers, wetlands and creeks that drain into the Lagos Lagoon are relatively scanty (Nwankwo \& Akinsoji, 1992). The paucity of bio-ecological information on water bodies that empty into the Lagos Lagoon prompted this work. The paper presents the results of a study conducted to evaluate the physical, chemical and macrobenthic invertebrate characteristics of selected swampy water bodies draining through the University of Lagos into the Lagos Lagoon, southern Nigeria.

\section{Materials and methods}

Fig. 1. shows the study sites within the University of Lagos $\left(20^{\circ} 50^{\prime} \mathrm{N} ; 30^{\circ} 50^{\prime} \mathrm{E}\right)$. Three sampling stations approximately $500 \mathrm{~m}$ apart were chosen for this study. Station A is located on the north-eastern side of the University of Lagos between the Faculties of Engineering and Science. The site is a brackish water swamp influenced by the tidal fluctuations of the Lagos Lagoon. The channel width at this site is about $2 \mathrm{~m}$ with an approximate depth of $0.08 \mathrm{~m}$. The sub-stratum is clayey mud. There were active holes of the crab species, Uca tangeri and Sesarma hazardii, on the firmer grounds. The dominant riparian vegetations were Elaeis guineensis, oil palm and shrubs such as Acrosticuum aureum, Ficus sp. and Alchornea cordifolia. A wooden footbridge across the marshy ground has been constructed at this site. Apart from the movement of pedestrians across the wooden bridge and the occasional fishing for crabs by young adults living in fishing camps by the University, this site was totally devoid of human activity. 


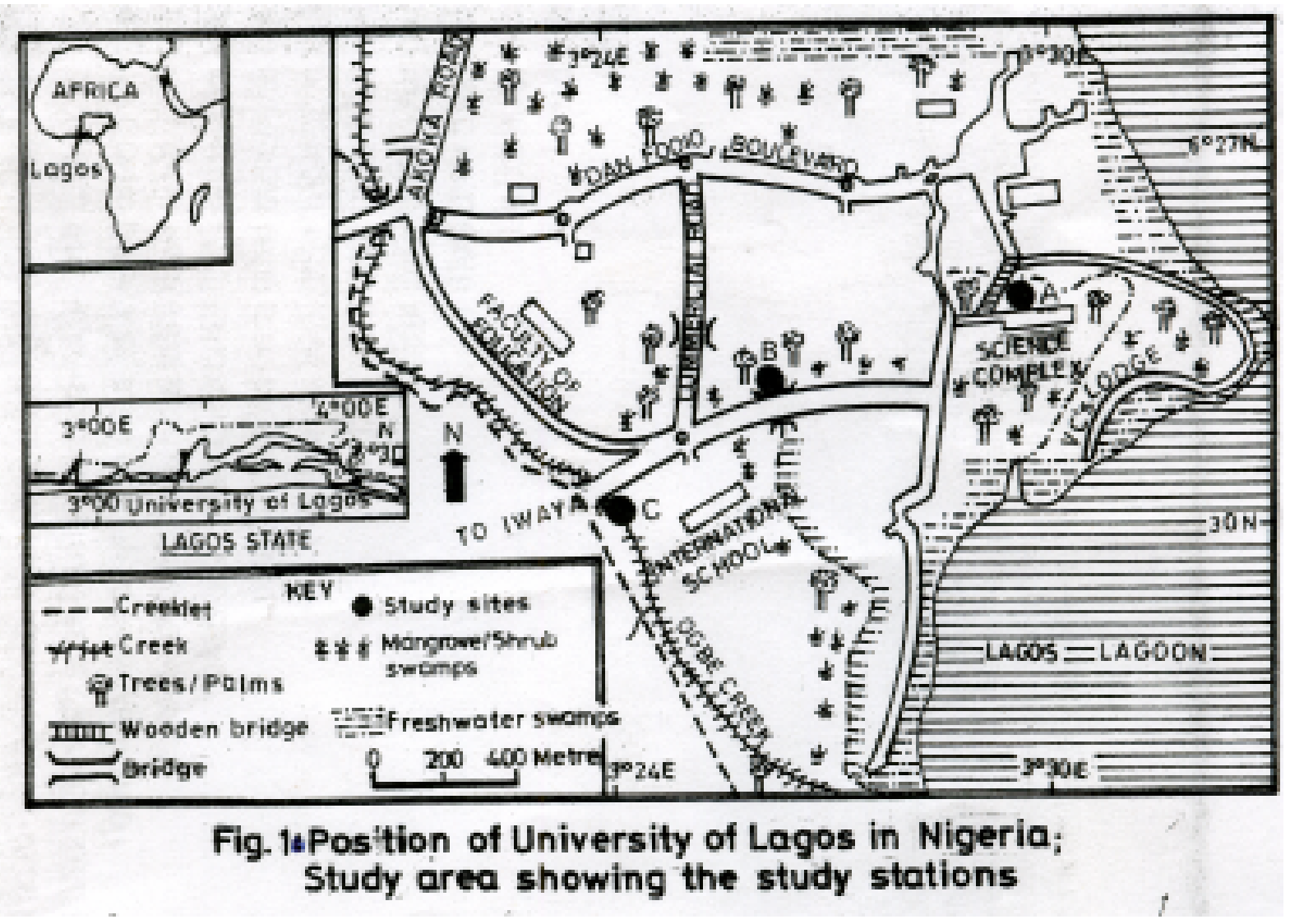

Fig. 1. Position of University of Lagos in Nigeria; Study area showing the study stations

Station B is located about $500 \mathrm{~m}$ from station A in an isolated freshwater swamp. This site, by the connecting access road to the University Secondary School, is a depositional pool with no obvious unidirectional flow. It is a part of a creeklet, which empties into the Lagos Lagoon. Floating macrophytes dominated by water lotus, Pistia stratiotes (water lily), covers the surface water at this site. Other aquatic vegetation includes Lemna paucicosta, Dryopteris sp., Vernonia amygdalina and Anthocleista vogelii. The substratum is muddy with a channel width of about $20 \mathrm{~m}$ and an average depth of about $0.5 \mathrm{~m}$. Human activity at this site was minimal and restricted to fishermen occasionally setting gill net and cane traps.

Station C is located about $1 \mathrm{~km}$ from station A on a swampy creek called the Ogbe creek, which flows south-west through the Lagos metropolis and University of Lagos before emptying into the lagoon. The creek is highly perturbed and receives various domestic and industrial effluents from heavily populated urban settlements along its route. The stream channel width is about $30 \mathrm{~m}$ with an average flow velocity of $0.5 \mathrm{cmS}^{-1}$. The water was malodorous and usually murky green to black in colour at this site. The floating aquatic vegetation is dominated by Echhornia crassipes (water hyacinth). The substratum is sandy mud. Human activity at the site was high and included direct defecation and channeling of sewage and other domestic waste into the stream.

Surface water for physical and chemical analysis and macroinvertebrate samples were collected in all three stations fortnightly between June and December, 2000. Samples were collected between 0900 and 1200 h on each occasion. The air and water temperatures were measured using a mercury-in-glass thermometer in ${ }^{\circ} \mathrm{C}$. The electrical conductivity was determined using a portable Ciba Corning conductivity meter (Model PPS/1604). A $p \mathrm{H}$ meter (Griffin 50) standardized with appropriate buffers was used to measure the hydrogen ion concen-tration. The iodometric Winkler's method (APHA, 1992) was used to determine the dissolved oxygen and $\mathrm{BOD}_{5}\left(\mathrm{mgl}^{-1}\right)$. The Mhor titration (APHA, 1992) was used to determine the chlorinity of the water from which the salinity (\%) was estimated using the formula:

$$
\text { Salinity }(\%)=1.8050 \times \text { Chlorinity }-0.030
$$

Chemical oxygen demand (COD), phosphate-phosphorus and nitrate-nitrogen (all in mgl-1) were determined in the water analysis laboratory of Federal Environmental Protection Agency, Lagos State, Nigeria. All standard methods used for these estimates were adopted from APHA (1992).

Sampling and laboratory procedures for studying macrobenthic invertebrates of shallow waters as described by Victor \& Ogbeibu $(1985,1991)$ were used in this study. The identification of Nigerian freshwater fauna is extremely 
difficult; therefore, many invertebrates were identified only to the generic level. The taxa recognized were, however, distinct morphological units. Manuals and literature used for taxonomic identifications are listed in Ogbeibu \& Victor (1989). The faunal community structure was analyzed using diversity and dominance indices (Odum, 1971; Krebs, 1978). Dif-ferences between genera diversity indices $(\mathrm{H})$ were tested for significance using Hutcheson's t-test (Hutcheson, 1970). Taxonomic similarities between pairs of stations were examined using the modified MorisitaHorn index and the Jaccard's coefficient (Wolda, 1981; Magurran, 1988). Specific methods are mentioned in the results. All appropriate statistical procedures for data analysis were adopted from Zar (1984).

\section{Physical and chemical conditions}

\section{Results and discussion}

The summary of the physical and chemical conditions analyzed in the study is presented in Table 1 . All factors with the exception of air temperature, $p \mathrm{H}$ and conductivity were significantly different among the three stations (ANOVA, $\mathrm{p}<0.05-0.01)$. An a posteriori comparison using Tukey's test for each factor showed that fluctuations in the means of all parameters were statistically similar at stations A and B except for water temperature which was significantly lower at station B than stations A and C (Table 1). Also, the multiple comparison test revealed that dissolved oxygen, nitrate-nitrogen and salinity were significantly lower, while BOD, COD and phophate-phosporus were significantly higher at station $\mathrm{C}$ than stations $\mathrm{A}$ and $\mathrm{B}$ (Table 1).

TABLE 1

Summary of physical and chemical characteristics of swampy water bodies in University of Lagos, June-December 2000 (Number of samples = 12/sation)

$\begin{array}{lllllll} & \text { Station } A & \text { Station } B & \text { Station } C & & & \\ \text { Physical conditions } & \text { Mean } \pm \text { SE } & \text { Min. } & \text { Max. } & \text { Mean } \pm S E & \text { Min. } & \text { Max. }\end{array}$

Temperature

(oC) Air

(oC) Water

\begin{abstract}
$26.39 \pm 1.01 \mathrm{a}$
\end{abstract}
$27.01 \pm 1.08 \mathrm{a}$
22.5

25
29.5

31

$$
26.65 \pm 0.99 \mathrm{a}
$$

$25.79 \pm 0.79 b$

\subsection{8}

24
30.5

28.5
$26.59 \pm 1.01 \mathrm{a}$

$28.03 \pm 1.21 \mathrm{a}$

Chemical Conditions

Conductivity ( $\mu$ mhos)

$6.92 \pm 0.23 a$

\subsection{7}

$3.97 \pm 1.53 \mathrm{a}$

0.1

$3.94 \pm 1.21 \mathrm{a}$

1.5

$561.38 \pm 168.9 a$

27

COD (mgl-1)

$\mathrm{PH}$

PO4-p (mgl-1)

NO4-n (mgl-1)

Salinity (\%o)

$\begin{array}{ll} & 6.7 \\ 2.89 \pm 1.19 \mathrm{a} & 0.59 \\ 9.86 \pm 2.94 \mathrm{a} & 4.1 \\ 8.56 \pm 1.92 \mathrm{a} & 2.5\end{array}$

$7.39 \pm 0.23 a$
$3.31 \pm 1.22 a$
$3.19 \pm 9.48 a$
$550.33 \pm 161.09 a$
$2.85 \pm 1.45 a$
$8.16 \pm 2.5 a$
$8.2 \pm 2.48 a$

6.6

0.4

2.48

44

6.6

0.46

2.95

0.5
8.1

7.5

5.5

909

8.1

7.5

19.13

12.1
$6.77 \pm 0.53 a$

$2.19 \pm 0.81 b$

$9.3 \pm 1.6 b$

$663.75 \pm 152.56 b$

$9.45 \pm 5.28 \mathrm{~b}$

$6.71 \pm 0.69 \mathrm{~b}$

$4.33 \pm 1.36 b$

a,b,c - means indicated with the same letters are not significantly different between stations (p > 0.05); ANOVA and subsequent $a$ posteriori comparison using Tukey’s test.

Faunal composition, abundance and distribution.

Table 2 shows the taxa composition, abundance and distribution of major invertebrate groups in the study stations. Forty-three taxa were recognized from a total of 2,424 individuals collected. Thirteen taxa (27.9\%) were collected from station A, while 34 (79.1\%) and 10 (23.3\%) taxa, respectively, were present in stations B and C. Chironomidae (25.8\%), Coroxidae (18.3\%), Naididae (16.4\%) and Culicidae (11.1\%) accounted for $71.6 \%$ of all individuals collected from all stations.

The overall composition and distribution of macrobenthic invertebrates in the swampy water bodies within University of Lagos, June December 2000; number of individuals in kick samples $/ 0.25 \mathrm{~m}^{2}$ surface of the substratum. Results of Krustkal-Wallis test and a posteriori multiple comparisons, * indicates significant difference ( $p<0.05)$; same letters denote no difference in stations 


\begin{tabular}{|c|c|c|c|c|c|c|c|c|}
\hline & $\begin{array}{l}\text { No. } \\
\text { of taxa }\end{array}$ & $\begin{array}{l}\text { Station A } \\
\text { individuals }\end{array}$ & $\begin{array}{l}\text { No. of } \\
\text { taxa }\end{array}$ & $\begin{array}{l}\text { S tation B } \\
\text { No. of } \\
\text { individuals }\end{array}$ & $\begin{array}{l}\text { Station C } \\
\text { No. of } \\
\text { of taxa }\end{array}$ & $\begin{array}{l}\text { No. } \\
\text { individuals }\end{array}$ & $\begin{array}{l}\text { All sites } \\
\text { No. of } \\
\text { of taxa }\end{array}$ & $\begin{array}{l}\text { No. of } \\
\text { individuals }\end{array}$ \\
\hline \multicolumn{9}{|l|}{ Oligochaeta } \\
\hline Naididae & 2 & $20 a$ & 3 & $362 b$ & 2 & 13a & 3 & 395 \\
\hline Tubificidae & - & - & 1 & 10 & 1 & 116 & 1 & 126 \\
\hline \multicolumn{9}{|l|}{ Collembolla } \\
\hline Isotomidae & - & - & 1 & 3 & - & - & 1 & 3 \\
\hline \multicolumn{9}{|l|}{ Ephemeroptera } \\
\hline Baetidae & - & - & 4 & 10 & - & - & 4 & 10 \\
\hline Lestidae & - & - & 1 & 1 & - & - & 1 & 1 \\
\hline \multicolumn{9}{|l|}{ Hemiptera } \\
\hline Pleidae & 1 & 1 & 1 & 441 & - & - & 1 & 442 \\
\hline Coroxidae & - & - & 1 & 20 & - & - & 1 & 20 \\
\hline Naucoridae & - & - & 1 & 1 & - & - & 1 & 1 \\
\hline Mesovalidae & - & - & 1 & 1 & - & - & 1 & 1 \\
\hline Notonectidae & - & - & 1 & 1 & - & - & 1 & 1 \\
\hline Belostomidae & - & - & 2 & 2 & - & - & 2 & 2 \\
\hline \multicolumn{9}{|l|}{ Coleoptera } \\
\hline Hydrophilidae & - & - & 1 & 10 & 1 & 1 & 1 & 11 \\
\hline Dytiscidae & - & - & 3 & 103 & - & - & 3 & 103 \\
\hline Hydraenidae & - & - & 1 & 3 & - & - & 1 & 3 \\
\hline Elmidae & - & - & 1 & 10 & - & - & 1 & 10 \\
\hline \multicolumn{9}{|l|}{ Odonata } \\
\hline \multicolumn{9}{|l|}{ Anisoptera } \\
\hline Gomphidae & - & - & 1 & 7 & - & - & 1 & 7 \\
\hline \multicolumn{9}{|l|}{ Zygoptera } \\
\hline Coenagriinidae & - & - & 1 & 9 & - & - & 1 & 9 \\
\hline \multicolumn{9}{|c|}{ Tricoptera } \\
\hline Psychomyiidae & - & - & 1 & 28 & - & - & 1 & 28 \\
\hline \multicolumn{9}{|c|}{ Diptera } \\
\hline Ceratopogonidae & 1 & 2 & 1 & 103 & - & - & 1 & 105 \\
\hline Chironomidae & 2 & $15 a$ & 2 & $587 b$ & 1 & $20 \mathrm{a}$ & 2 & 622 \\
\hline Tipulidae & - & - & - & - & 1 & 7 & 1 & 7 \\
\hline Tabanidae & - & - & - & - & 1 & 20 & 1 & 20 \\
\hline Culicidae & 4 & $22 \mathrm{a}$ & 4 & $143 b$ & 2 & $103 c$ & 4 & 268 \\
\hline Dixidae & 1 & 2 & 1 & 3 & 1 & 2 & 1 & 7 \\
\hline Syrphidae & - & - & 1 & 4 & 1 & 6 & 1 & 10 \\
\hline \multicolumn{9}{|l|}{ Arachnida } \\
\hline Hydrachnellae & 1 & 1 & 1 & 156 & - & - & 1 & 157 \\
\hline \multicolumn{9}{|l|}{ Decapoda } \\
\hline Palaemoniidae & 1 & 10 & 1 & 15 & - & - & 1 & 32 \\
\hline Bulinidae & - & - & 1 & 7 & - & - & 1 & 7 \\
\hline \multicolumn{9}{|l|}{ Hirudinea } \\
\hline Pisciolidae & - & - & 1 & 1 & - & - & 1 & 1 \\
\hline Glossiphoridae & - & - & 1 & 3 & - & - & 1 & 3 \\
\hline \multirow[t]{2}{*}{ Nematoda } & 1 & 12 & - & - & - & - & 1 & 12 \\
\hline & 12 & 85 & 34 & 2044 & 10 & 288 & 43 & 2424 \\
\hline
\end{tabular}

The overall abundance was significantly different at the three stations (Kruskal-Wallis test, $\mathrm{p}<0.05$ ). An $a$ posteriori test for non-parametric multiple comparison showed that the abundance at station $\mathrm{B}$ was significantly higher than those at stations $A$ and $C(p<0.05)$, which were not different from each other $(\mathrm{p}>0.05)$. Of all individuals collected 2,044 (84.3\%) were from station B. Table 3 shows the distribution of macroinvertebrate genera and/or species at the three stations. Information from these data is utilized to detect habitat preference and perturbation tolerant taxa at the study stations.

TABLE 3

The distribution of the macrobenthic invertebrate genera in the swampy water bodies at the study stations within the University of Lagos. $+=$ Presence

Taxon Study stations

$$
\text { A } \quad B \quad C
$$

Oligochaeta

Nais 


\begin{tabular}{|c|c|c|c|}
\hline Dero & + & + & + \\
\hline Aulophorus & & + & \\
\hline Tubifex & & + & + \\
\hline \multicolumn{4}{|l|}{ Collembolla } \\
\hline Isotoma & & + & \\
\hline \multicolumn{4}{|l|}{ Ephemeroptera } \\
\hline Baetis & & + & \\
\hline Cloeon & & + & \\
\hline \multirow[t]{2}{*}{ Taxon } & \multicolumn{3}{|c|}{ Study stations } \\
\hline & $A$ & $B$ & $C$ \\
\hline Centroptilum & & + & \\
\hline Procloeon & & + & \\
\hline Lestes & & + & \\
\hline \multicolumn{4}{|l|}{ Hemiptera } \\
\hline Micronecta & & + & \\
\hline Lethocerus & & + & \\
\hline Notonecta & & + & \\
\hline Plea & & + & \\
\hline Mesoveoia & & + & \\
\hline Pelocoris & & + & \\
\hline Belostoma & & + & \\
\hline \multicolumn{4}{|l|}{ Coleoptera } \\
\hline Hydrobius & & + & \\
\hline Helophorus & & + & \\
\hline Agabus & & + & \\
\hline Derenctes & & + & \\
\hline Bidessus & & + & \\
\hline Elmis & & + & \\
\hline \multicolumn{4}{|l|}{ Odonata } \\
\hline \multicolumn{4}{|l|}{ Anisoptera } \\
\hline Gomphus & & + & \\
\hline \multicolumn{4}{|l|}{ Zygoptera } \\
\hline Coenagrion & & + & \\
\hline \multicolumn{4}{|l|}{ Tricoptera } \\
\hline Tinodes & & + & \\
\hline \multicolumn{4}{|l|}{ Diptera } \\
\hline Allaudomyia & & + & \\
\hline Chironomus & + & + & \\
\hline Polypedilum & + & + & \\
\hline Tapula & & & + \\
\hline Tabanus & & & + \\
\hline Culex & + & + & + \\
\hline Aedes & + & + & \\
\hline Mansonia perturbans & + & + & \\
\hline Anopheles & + & + & + \\
\hline Dixa & + & + & + \\
\hline Eristalis bastardii & & + & + \\
\hline \multicolumn{4}{|l|}{ Hydrachnellae } \\
\hline Hydrophantes & + & + & \\
\hline \multicolumn{4}{|l|}{ Hirudinea } \\
\hline Pisciola & & + & \\
\hline Glossiphonis & & + & \\
\hline \multicolumn{4}{|l|}{ Decapoda } \\
\hline Macrobrachium macrobrachion & & + & \\
\hline Bulinus & & + & \\
\hline Nematoda & & & \\
\hline Indet. 1 & + & & \\
\hline
\end{tabular}

\section{Diversity and dominance}

Table 4 presents the diversity and dominance indices calculated for the three stations. Taxon richness (d) and Shannon's diversity $(\mathrm{H})$ followed the same pattern at the study sites. Both were highest at station B and lowest at station C. Shannon's diversity at the three stations were significantly different from each other (Hutcheson's t-test; $\mathrm{p}<$ 0.01). Evenness at stations $A$ and $C$ were similar and slightly higher than evenness at station B. Concentrated dominance as shown by Simpson’s dominance (C) indices was higher at station C than stations A and B. 
Diversity of macrobenthic invertebrates in the swampy water study stations within the University of Lagos, June - December 2000. * Hutcheson's t-test - significantly different $(p<0.01)$

$\begin{array}{lccc} & \text { Station } & \text { Station } & \text { Station } \\ & A & B & C \\ \text { No. of samples } & 12 & 12 & 12 \\ \text { No. of taxa } & 13 & 34 & 10 \\ \text { No. of individuals } & 85 & 2044 & 288 \\ \text { Taxon richness (d) } & 6.65 & 12.99 & 3.66 \\ \text { Genera diversity (H) } & 0.758^{*} & 0.885^{*} & 0.625^{*} \\ \text { Evenness (E) } & 0.661 & 0.539 & 0.625 \\ \text { Dominance (C) } & 0.191 & 0.178 & 0.302\end{array}$

Faunal similarity

Summary of the faunal similarities at the study stations is presented in Table 5. Morisita-Horn index showed that only stations A and B were significantly similar $(\mathrm{p}<0.05)$. Jaccard's coefficient indicated that all the stations were significantly dissimilar $(\mathrm{p}<0.01)$.

TABLE 5

Faunal comparisons of macrobenthic invertebrates in the study stations of the swampy water bodies within the University of Lagos. Numbers in italics Morisita-Horn index, * significant similarity $\geq 50 \%$. Numerals in bold Jaccard index, * significant dissimilarity ( $p<0.05)$

\begin{tabular}{llll} 
& \multicolumn{3}{c}{ Stations } \\
& A & B & $C$ \\
Station A & - & $0.59^{*}$ & 0.44 \\
Station B & $0.74^{*}$ & - & 0.19 \\
Station C & $0.77^{*}$ & $0.79^{*}$ & -
\end{tabular}

The quality of an aquatic ecosystem depends on environmental factors, which in turn can influence the structuring of aquatic communities. Therefore, it is usually desirable to identify these environmental factors (Richards, Host \& Arthur, 1993; Victor \& Onomivbori, 1996). With the exception of water temperature, station C was significantly dissimilar in concentrations of all physical and chemical parameters investigated from stations A and B, which were relatively similar. Station $\mathrm{B}$ was shaded by riparian vegetation and this was responsible for the low water temperature observed at this site. The dissolved oxygen, $\mathrm{BOD}_{5}, \mathrm{COD}, \mathrm{PO}_{4-\mathrm{p}}$ and $\mathrm{NO}_{3-\mathrm{n}}$ concentra-tions at station $\mathrm{C}$ indicated deterioration in water quality. These values were compar-able to those of earlier reports of polluted sections of Lagos Lagoon (Akpata \& Ekundayo, 1978; Ajao, Fagade \& Oyenekan, 1991) and Ikpoba River (Victor \& Ogbeibu, 1991; Victor \& Onomivbori, 1996).

Phosphate-phosphorus usually occurs in small amount in aquatic ecosystems (Tait \& Dipper, 1998) but the values reported in this study were high especially at station C (Table 1) compared to those reported for most Nigerian water bodies (Victor \& Onomivbori, 1996; Edokpayi et al., 2000). The contribution from domestic effluents rich in detergents and other organic pollutants was responsible for the elevated values. Phospate and other chemical substances are known to occur in high concentration in water bodies receiving organic effluents (Kronvang, 1992; Faafeng \& Roetth, 1993). Organic effluent and the extensive use of detergent have been reported to affect aquatic taxa (Harrison \& Hynes, 1988; Victor \& Onomivbori, 1996).

Salinity levels at stations A and B was similar and relatively higher than at station C. This was a reflection of the tidal influence of the Lagos Lagoon that was more pronounced at stations A and B than at station C. As changes in water quality conditions could directly influence the structure of aquatic benthic communities (Battegazzore et al., 1992; Bunn \& Davies, 1992; Camargo, 1992; Victor \& Onomivbori, 1996), it appears that the significantly different physical and chemical parameters at the three stations influenced the structure of the macroinvertebrate communities at these sites.

Using the number of macrobenthic invertebrate taxa and abundance pattern, the study sites could be ordered as $B$ > A $>$ C and B > C > A, respectively. Station B was relatively unperturbed compared to stations A and C, hence the higher number of taxa observed at station B was not unexpected. The small channel width and the periodic reduction in water volume due to tidal influence of the Lagos Lagoon at station A exerted physical stress at this site. Effluents from various activities ranging from vehicle washing, surface run-off from auto-mechanic workshops and domestic 
discharges released into the Ogbe creek along its route were responsible for the poor water quality and low number of taxa observed at station C.

Bank-root biotope invertebrates are more tolerant to perturbations and, therefore, the distribution and abundance of specific bank-root taxa could be of use in assessing the environmental status of the study stations (Victor \& Onomivbori, 1996). With the exception of Aulophorus, all oligochaetes recorded seem to have some level of tolerance to aquatic perturbation (Table 3). Particularly, the occurrence of Tubifex in station C reflect the ability of this oligochaete to tolerate and exploit perturbed environment. Tubificids have been reported to thrive successfully in organically polluted environment (Mason, 1991). Naidids responded to organic pollution in the study area by increasing in abundance (Table 2). This trend is similar to earlier observations in similar water bodies (Learner,Lochhead \& Hughes, 1978; Victor \& Onomivbori, 1996).

Collembolla, Ephemeroptera, Hemiptera, Coleoptera, Odonata, Hydrachnellae and Hirudinea were only recorded in station B. Their absence in stations A and C reflects their sensitivity to organic and inert pollution. The dense coverage of the pool water by floating vegetations dominated by Pistia stratiotes (water lotus) at station B created suitable habitat for these macroin-vertebrates. Response of ephemeropterans to perturbation is varied depending on geographical location and type of perturbation (Victor \& Onomivbori, 1996). Some ephemeropterans have been known to tolerate moderate to severe organic pollution (Hellawell, 1986). The five taxa, Baetis, Cloeon, Centroptilum, Procloeon and Lestes, recorded appear to be sensitive to poor water quality as reflected by their absence in stations A and C. However, some of the taxa have been reported to exhibit some level of tolerance to organic pollution (Victor \& Onomivbori, 1996). Four of the five ephemeropterans were baetids, which are facultatively herbivorous and are found among aquatic vegetation (Mellanby, 1963; Hynes, 1970; Ogbeibu \& Victor, 1989). This may have influenced their occurrence in station $B$, which was covered by aquatic macrophytes.

Dipterans were recorded at all three study sites. Generally, the ecological requirements of individual taxa appear to regulate their spatial distribution and abundance. The only ceratopogonid taxon recorded was Allaudomyia that was more abundant in station B. Larvae of this taxon are known to be common among aquatic plants (Ogbeibu, 2001). The overall pattern of invertebrate distribution and abundance at the study sites was influenced by Chirono-midae (Tables 2 and 3), which usually show no habitat restrictions (Awachie, 1981; Ogbeibu \& Victor, 1989) and are known to replace other invertebrate taxa in water bodies perturbed by agricultural and domestic activities (Victor \& Ogbeibu, 1985). The abundance of the two chironomid taxa, Chironomus and Polypedilum, at stations B and C appears to have been governed by their ecological requirements such as high organic matter, abundance of organic debris, broad oxygen tolerence and muddy substratum (Petr, 1972; Ogbeibu, 2001). Tipulids generally are intolerant of organic pollution (Hellawell, 1986); the occurrence of Tipula at station C (the site exposed to domestic wastes) is, however, not clear.

Diversity indices as estimated by taxa richness (d), genera diversity $(\mathrm{H})$ and evenness (E) varied among the stations. The significantly higher diversity and taxa richness at station B is a reflection of its ecological heterogeneity and stability (Ogbeibu, 2001). The low dominance (C) at station B further justifies the high diversity at this site. The low taxa richness and genera diversity at station $\mathrm{C}$ in addition to the high dominance further confirms the perturbed condition. High dominance at this site was caused by the elevated abundance of tolerant Chironomidae, Pleidae and Naididae taxa.

The faunal comparisons of the three study stations clearly showed that station C was dissimilar from stations A and $\mathrm{B}$, which were relatively similar. Morisita-Horn index measures quantitatively the species similarity between sites and it is not strongly influenced by species richness and sample size (Wolda, 1981; Magurran, 1988). Jaccard's coefficient excludes negative matches and accounts only for the mutual presence of taxa (Slack, Nauman \& Tilley, 1979; Ogbeibu \& Victor, 1989). The dissimilarity of station C, which was exposed to domestic and urban discharges that accounted for the degradation of the water quality, was validated by both tests. The number of benthic taxa reported for station C was similar to that reported for polluted sections of some water bodies in Nigeria (Victor \& Onomivbori, 1996). Generally, the differ-ences in the abundance, occurrence and number of species at the study site was influenced by the level of exposure to urban discharges, inert pollutant and the presence of aquatic macrophytes.

\section{Acknowledgement}

The authors thank Dr (Mrs) C. A. Ogunwenmo, Mr Bolaji Dunsin and the staff of the Marine Biology Laboratory of University of Lagos, for their assistance in the collection, analysis and identification of the specimens. Their thanks also go to the two unnamed reviewers for their painstaking and detail review of the manuscript.

\section{References}

Ajao E. A., Fagade S. O. and Oyenekan J. A. (1991). The ecology of Aloidis trigona in Lagos lagoon, Nigeria. Arch. Hydrobiol. 121: 485-496.

Akpata, T. V. I. and Ekundayo, J. A. (1978). Faecal pollution of the Lagos lagoon. Niger. Sci. 12 (1 \& 2): 39-49. 
APHA (American Public Health Association) (1992). Standard Methods for the Examinati of Water and Wastewater, 18th edn. Washington, D.C.: American Public Health Association. 1268 pp.

Battegazzore M., Petersen Jr. R .C., Moretti, G. and Rossaro B. (1992). An evaluation of the environmental quality of the River Po using macroinvertebrates. Arch. Hydrobiol. 125: 175 - 206.

Awachie, J. B. E. (1981). Running water ecology in Africa. In Perspectives in Running Water Ecology. (M. A. Lock and D. D. Williams, ed.), pp. 339-366. New York, Plenum Press.

Brown C. A. and Oyenekan, J. A. (1998). Temporal variability in the structure of benthic macrofauna communities of the Lagos lagoon and harbour, Nigeria. Pol. Arch. Hydrobiol. 45 (1): 45-54.

Bunn S. E. and Davies, P. M. (1992). Community structure of macroinvertebrate fauna and water quality of a saline river system in south-western Australia. Hydrobiologia 248: 143-160.

Carmago J. A. (1992). Macroinvertebrate responses along the recovery gradient of a regulated river (Spain) receiving an industrial effluent. Arch. Envir. Contam.Toxicol. 23: 324-332.

Edokpayi C. A., Okenyi J. C., Ogbeibu A. E. and Osimen E. C. (2000). The effect of human activities on the macrobenthic invertebrates of Ibiekuma Stream, Ekpoma, Nigeria. Biosci. Res. Communs. 12 (1): $79-87$.

Faafeng B. A. and Roseth R. (1993). Retention of nitrogen in small streams artificially polluted with nitrate. Hydrobiologia. 251: 113-122.

Fagade S. O. and Olaniyan C. I. O. (1974). Seasonal distribution of the fish fauna of the Lagos lagoon. Bull. De IFAN Ser. A. 36 (1): 244-252.

Harrison A. D. and Hynes H. B. N. (1988). Benthic fauna of Ethiopia maintain streams and rivers. Arch. Hydrobiol. Suppl. 81: 1-36.

Hellawell J. M. (1986). Biological Indicators of Water Pollution and Environmental Management. Elsevier Applied Science Publisher. New York: 546 pp.

Hutcheson K. (1970). A test for comparing diversities based on the Shannon formula. J. theoret. Biol. 29: 151-4.

Hynes H. B. N. (1970). The Ecology of Running Waters. Toronto: University of Toronto Press. 555 pp.

Krebs C. J. (1978). Ecology: The Experimental Analysis of Distribution and Abundance, 2nd edn. New York: Harper International.

Kronvang B. (1992). The export of particulate matter, particulate phosphorus and dissolved phosphorus from two agricultural river basins: implications on estimating the non-point load. Wat. Res. 26: 1347-1358.

Learner M. A., Lochhead G. and Hughes B. D. (1978). A review of the biology of British

Naididae (Oligochaeta) with emphasis on the lotic environment. Freshwat. Biol. 8: 357-375.

Magurran A. (1988). Ecological diversity and its measurements. London: Crowm Helm. 1976 pp.

Mason C. F. (1991). Biology of Freshwater Pollution. 2nd edn. Essex: Longman Scientific \&Technical. 351 pp.

Mellanby H. (1963). Animal Life in Freshwater: A Guide to Freshwater Invertebrates. London: Chapman \& Hall. 308 pp.

Nwankwo D. I. (1988). A preliminary checklist of planktonic algae in Lagos lagoon, Nigeria. Niger. J. Bas. Appl. Sci. 2: 73-85.

Nwankwo D. I. and Akinsoji A. (1992). Epiphyte community on water hyacinth Eichhornia crassipes (MART.) SOLMS in coastal waters of southwestern Nigeria. Arch. Hydrobiol. 124 (4): 501-511.

Odum E. P. (1971). Fundamentals of Ecology, 3rd edn. London: W.B. Sanders. 546 pp.

Ogbeibu A. E. (2001). Distribution, density and diversity of dipterans in a temporary pond in Okomu forest reserven, southern Nigerian. J. aquat. Sci. 16: 43-52.

Ogbeib A. E. and Victor R. (1989). The effect of road and bridge construction on the bank-root macrobenthic invertebrates of a southern Nigerian stream. Envir. Pollut. 56: 85-100.

Olaniyan C. I. O. (1968). An Introduction to West African Animal Ecology. London \& Ibadan: Heinemann. 167 pp.

Petr T. (1972). Benthic fauna of a tropical man-made lake (Volta Lake, Ghana, 1965-1968). Archiv . Hydrobiol. 70: 484-533.

Richards C., Host, G. E. and Arthur J. W. (1993). Identification of predominant environmental factors structuring stream macroinvertebrate communities within a large agricultural catchments. Freshwat. Biol. 29: 285-294.

Solarin B. B. (1998). The hydrobiology, fishes and fisheries of the Lagos lagoon, Nigeria. (PhD Thesis.) University of Lagos. 235 pp.

Slack K. V., Nauman, J. W. and Tilley L . J. (1979). Benthic invertebrates in north flowing stream and a southflowing stream, Brooks Range, Alaska. Wat. Res. Bull. 15: 108-35.

Tait R. V. and Dipper F. A. (1998). Elements of Marine Ecology, 4th edn. Oxford: Butterworth-Heinemann. 462 pp.

Victor R. and Ogbeibu A. E. (1985). Macrobenthic invertebrates of a stream flowing through farmlands in southern Nigeria. Envir. Pollu. Ser. A. 39: 337-349.

Victor R. and Ogbeibu, A. E. (1991). Macroinvertebrate communities in the erosional biotope of and urban stream in Nigeria. Trop. Zool. 4: 1-12. 
Victor R. and Onomivbori O. (1996). The effects of urban perturbations on the benthic macroinvertebrates of a southern Nigerian stream. pp. 223-238. In Perspectives in Tropical Linmology. (F. Schiemer and K .T. Biland, ed.). Amsterdam, The Netherlands: SPB Academic Publishing.

Wolda H. (1981). Similarity indices, sample size and diversity. Oecologia 50: 296-302.

Zar J. H. (1984). Biostatistical Analysis, 2 edn. New Jersey: Prentice-Hall. 718 pp. 